\title{
Perlindungan hukum nasabah asuransi dalam upaya mewujudkan prinsip Good Corporate Governance
}

\author{
Feibe Engeline Pijoh ${ }^{\text {a, }}{ }^{*}$ \\ a Program Studi Ilmu Hukum FIS Unima, Manado, Indonesia \\ ${ }^{1}$ feibepijoh@yahoo.com \\ *korespondensi penulis
}

\begin{tabular}{ll}
\hline \multicolumn{2}{l}{ Informasi artikel } \\
\hline Sejarah artikel: & \\
Diterima & $: 23-10-2019$ \\
Revisi & $: 12-11-2019$ \\
Dipublikasikan & $: 7-12-2019$ \\
\hline
\end{tabular}

Kata kunci:

Perlindungan Hukum

Nasabah Asuransi,

Prinsip Good Corporate

Governance

\begin{abstract}
ABSTRAK
Pembangunan ekonomi di Indonesia jika didasarkan pada usaha untuk penegakkan demokrasi secara ekonomi, maka demokrasi ekonomi itu akan dilakukan berdasarkan pada prinsip kebersamaan, prinsip efisiensi, prinsip berkeadilan, berkelanjutan, prinsip berwawasan lingkungan, prinsip kemandirian dan prinsip menjaga keseimbangan serta prinsip kesatuan ekonomi secara nasional. Lembaga asuransi sebagai lembaga keuangan nonbank dalam kehidupan masyarakat terutama dalam kegiatan perdagangan atau perniagaan memegang peranan yang sangat penting karena fungsinya yang mengambil alih resiko yang seharusnya diderita sendiri, akan tetapi dengan adanya perjanjian asuransi maka kemudian resiko tersebut dialihkan kepada pihak yang lain, dalam hal ini yaitu pihak penanggung (perusahaan asuransi), bersedia untuk menanggungnya. Masalah dalam penelitian ini adalah bagaimanakah pengaturan tentang perlindungan hukum pada nasabah asuransi dan bagaimanakah prinsip Good Corporate Governance ini diterapkan dalam perusahaan asuransi. Penelitian ini bertujuan untuk mengkaji tentang berbagai peraturan yang berhubungan dengan Perasuransian dengan menganalisis peraturan-peraturan tersebut telah memberikan perlindungan hukum kepada nasabah asuransi, juga untuk menelaah dan mengkaji berbagai hal dalam pengaturan perlindungan hukum nasabah asuransi di Indonesia dalam upaya penerapan prinsip Good Corporate Governance.
\end{abstract}

\section{Keywords:}

Legal protection

Insurance Customers

Principles of Good Corporate

Governance

\section{ABSTRACT}

Economic development in Indonesia if based on efforts to uphold democracy in an economic manner, economic democracy will be carried out based on the principle of togetherness, the principle of efficiency, the principle of justice, sustainability, the principle of being environmentally sound, the principle of independence and the principle of maintaining balance and the principle of national economic unity. Insurance institutions as non-bank financial institutions in people's lives, especially in trading or commerce activities play a very important role because its function is to take over the risks that should be suffered alone, but with the insurance agreement then the risk is transferred to other parties, in this case namely the guarantor (insurance company), is willing to bear it. The problem in this study is how is the regulation on legal protection for insurance customers and how the principles of Good Corporate Governance are applied in insurance companies. This study aims to examine various regulations relating to Insurance by analyzing the regulations that have provided legal protection to insurance customers, as well as to examine and examine various matters in the legal protection arrangements for insurance customers in Indonesia in the application of the principles of Good Corporate Governance. 


\section{Pendahuluan}

Ditetapkannya Undang-undang Nomor 2 Tahun 1992 tentang Usaha Perasuransian dan telah diganti dengan Undang-undang No 40 Tahun 2014 tentang Perasuransian, maka telah terdapat salah satu perangkat hukum bagi industri perasuransian yang merupakan salah satu unsur lembaga keuangan, yang diharapkan dapat berperan dalam menanggulangi risiko yang dihadapi anggota masyarakat dan sekaligus merupakan suatu lembaga penghimpun dana masyarakat. Dalam memperkuat pelaksanaan fungsi perusahaan perasuransian, perlu diberikan kesempatan yang seluas-luasnya kepada para pihak yang akan melakukan usaha di bidang perasuransian, sekaligus dengan penegasan bahwa penyelenggaraan kegiatan usaha tersebut dilakukan secara sehat dan bertanggung jawab, serta tidak akan menelantarkan kepentingan masyarakat umum, atau tertanggung khususnya. Untuk itu, dalam melaksanakan kegiatan usahanya perusahaan perasuransian perlu tetap mempertahankan ketaatannya pada syarat-syarat penyelenggaraan usaha, termasuk mengenai tingkat kesehatan usaha.

Asuransi sebagai salah satu lembaga keuangan non Bank, bergerak dalam bidang pertanggungan merupakan sebuah lembaga yang lebih modern, yang diadopsi dari luar negeri, yang lahir bersamaan dengan adanya semangat pencerahan (reinaissance). Dalam kehidupan masyarakat modern sekarang ini, keberadaaan asuransi yang hadir sebagai lembaga keuangan yang bergerak dalam bidang pertanggungan bukanlah merupakan suatu hal yang baru. Bahkan dalam perkembangannya keberadaan asuransi sangat dibutuhkan untuk menghindarkan adanya suatu resiko yang mungkin muncul dikemudian hari, seperti resiko kebakaran, kecelakaan, pencurian, kebanjiran, sampai kepada resiko meninggalnya seseorang dalam asuransi jiwa.

Lembaga asuransi sebagai lembaga keuangan non bank dalam kehidupan masyarakat terutama dalam kegiatan perdagangan atau perniagaan memegang peranan yang sangat penting karena fungsinya yang mengambil alih resiko yang seharusnya ditanggung sendiri karena adanya perjanjian asuransi maka kemudian resiko tersebut dialihkan kepada pihak lain dalam hal ini penanggung (perusahaan asuransi) yang bersedia untuk menanggungnya. Oleh karena itu setiap hubungan yang terjadi antara produsen dan konsumen dalam kegiatan perdagangan atau perniagaan selalu melibatkan lembaga asuransi atau pertanggungan.

Secara yuridis, belum terakomodasinya perlindungan hukum bagi nasabah secara jelas dalam perundangundangan tentang Asuransi dan bahkan peraturan-peraturan lain yang berhubungan dengan asuransi. Sedangkan secara teoritis, keadaan dan perkembangan dalam masyarakat yang belum sepenuhnya mendapatkan perlindungan hukum yang dihubungkan dengan penerapan terhadap prinsip Good Corporate Governance pada perusahaan asuransi yang akan memberikan perlindungan kepada nasabah asuransi.

Berdasarkan kenyataan yang ada saat ini, oleh penulis merasa tertarik untuk meneliti dengan memberikan sumbangan pemikiran secara ilmiah untuk mengkaji hal-hal tentang perlindungan bagi nasabah asuransi dan penerapan prinsip Good Corporate Governance pada perusahaan asuransi.

Permasalahan dalam penelitian ini sebagai berikut: (1). Bagaimanakah pengaturan tentang perlindungan hukum bagi nasabah asuransi? (2). Bagaimanakah penerapan prinsip Good Corporate Governance dalam perusahaan asuransi?

\section{Metode}

Penelitian ini merupakan penelitian hukum normatif (legal research), karena dalam penelitian ini akan mengkaji dan menganalisa peraturan-paraturan yang berhubungan dengan Usaha Perasuransian.

Untuk mendapatkan kejelasan dari permasalahan yang ada maka pendekatan permasalahan yang akan digunakan dalam 
penelitian ini meliputi: pendekatan filsafat (philosophical approach), pendekatan konseptual (conceptual approach), pendekatan perundang-undangan (statute approach), pendekatan perbandingan hukum (comparative approach) (Ibrahim, 2008).

a. Pendekatan Filsafat (philosophical approach), dalam penelitian ini mengkaji masalah Asuransi yang meliputi hakikat, nilai dan makna tujuan asuransi.

b. Pendekatan Konseptual (conceptual approach), yaitu mengkaji faktor-faktor yang mengakibatkan tidak adanya keserasian dan keharmonisan peraturan tentang asuransi dalam hal tidak adanya perlindungan yang optimal terhadap dana nasabah, memberikan perlindungan kepada nasabah asuransi dengan menerapkan prinsip Good Corporate Governance.

c. Pendekatan Perundang-Undangan (statute approach), yaitu menelaah peraturan yang berlaku dan peraturan perundangan yang berhubungan erat dengan asuransi serta untuk mendapatkan kejelasan dan kesesuaian serta pembuatan peraturan khusus tentang perlindungan nasabah asuransi.

Bahan hukum yang dikaji pada penelitian ini meliputi:

a. Bahan hukum primer, yaitu peraturan perundang-undangan yang mengatur tentang Usaha Perasuransian, UU Perlindungan Konsumen, UU Perbankan, UU Penanaman Modal.

b. Bahan hukum sekunder, yang terdiri dari buku-buku, jurnal ilmiah yang berhubungan dengan Usaha Perasuransian.

c. Bahan hukum tersier, terdiri dari berbagai jenis kamus, seperti kamus hukum, kamus besar bahasa Indonesia (KBBI), serta kamus yang lain.

Pengumpulan bahan hukum primer dan bahan hukum sekunder, menggunakan teknik dokumenter dan dilakukan dengan menggunakan sistem kartu (card system), kemudian diinventarisir dan dikelompokkan (klasifikasi) sesuai dengan masing-masing rumusan masalah.
Bahan hukum yang telah
dikumpulkan dan dikelompokkan kemudian ditelaah dengan pendekatan filosofis, konseptual, perundang-undangan serta perbandingan hukum, untuk memperoleh gambaran terhadap permasalahan perlindungan nasabah asuransi yang adil dan demokratis, dengan menggunakan penafsiran atau interpretasi gramatikal, sistematis atau logis, komperatif atau teleologis. Selanjutnya dilakukan analisis dengan memakai analisis kualitatif, yaitu menelaah, menjelaskan secara mendalam dan menyeluruh serta saling berkaitan satu dengan lainnya, dan mengevaluasi bahan hukum, sebagai penjabaran dari pelaksanaan perlindungan nasabah asuransi dengan menerapkan prinsip Good Corporate Governance pada perusahaan asuransi.

\section{Hasil dan Pembahasan}

Teori Perlindungan Hukum, berdasarkan temuan dari Philipus $M$. Hadjon, mengartikan pengertian perlindungan hukum sebagai suatu perlindungan tentang harkat dan martabat, juga adanya pengakuan pada hak asasi manusia, yang didapati oleh subyek hukum berdasarkan ketentuan hukum dari kesewenangan (Hadjon, 1987).

Adanya perlindungan hukum dari tindakan yang dilakukan oleh pemerintah, yang mana bersumber dari konsep tentang pengakuan dan adanya perlindungan akan hak-hak asasi manusia, oleh karena berdasarkan sejarah dari Barat, dimana adanya konsep-konsep pengakuan serta perlindungan hak-hak asasi manusia akan ditujuksn pada pengertian dan peletakan kewajiban pada masyarakat dan pada pemerintah.

Untuk merumuskan prinsip-prinsip perlindungan hukum yang ada di Indonesia, maka landasannya adalah Pancasila sebagai Sumber segala sumber hukum, juga sebagai ideologi dan falsafah bagi bangsa Indonesia. Konsep perlindungan hukum bagi masyarakat di luar negeri, bersumber pada konsep-konsep Rechtstaat, dan juga 
Rule of The Law. Dimana menggunakan konsepsi Barat sebagai acuan untuk mengkaji serta berfikir dengan dasar Pancasila, prinsip perlindungan pada hukum di Indonesia adalah prinsip pengakuan dan perlindungan terhadap harkat dan martabat manusia yang bersumber pada Pancasila. Prinsip perlindungan hukum terhadap tindakan pemerintah berdasar serta bersumber pada konsep tentang pengakuan dan perlindungan terhadap HAM, karena menurut sejarah di Barat, adanya konsep tentang pengakuan dan perlindungan terhadap HAM tersebut ditujukan kepada pembatasan-pembatasan dan peletakan kewajiban masyarakat dan pemerintah.

Perlindungan hukum secara khusus bagi masyarakat Indonesia, menurut Philipus M. Hadjon, terdapat dua jenis perlindungan hukum, yaitu:

1. Perlindungan Hukum secara Preventif Perlindungan hukum preventif dikhususkan pada subyek hukum, yangmana akan diberikan kesempatan untuk mengajukan keberatan atau pendapatnya sebelum suatu keputusan pemerintah mendapat bentuk yang definitif. Tujuannya adalah mencegah terjadinya sengketa. Perlindungan hukum preventif sangat besar artinya bagi tindak pemerintahan yang didasarkan pada kebebasan bertindak karena dengan adanya bentuk perlindungan hukum dalam arti preventif, maka pemerintah terdorong untuk bersifat hati-hati dalam mengambil keputusan yang didasarkan pada diskresi. Di indonesia belum ada pengaturan khusus tentang perlindungan hukum secara preventif.

2. Sarana Perlindungan Hukum Secara Represif

Perlindungan hukum yang represif bertujuan untuk menyelesaikan sengketa. Penanganan perlindungan yang dilakukan oleh Pengadilan Umum dan Peradilan Administrasi di Indonesia termasuk kategori perlindungan hukum ini.

\section{Konsep Perlindungan Hukum}

Terdapat beberapa pandangan yang dapat dikutip sebagai suatu patokan mengenai perlindungan hukum, yaitu:

a. Menurut Satjipto Rahardjo, perlindungan hukum adalah adanya upaya melindungi kepentingan seseorang dengan cara mengalokasikan suatu kekuasaan kepadanya dalam bertindak untuk kepentingannya (Rahardjo, 20014).

b. Pendapat dari Setiono tentang perlindungan hukum yaitu suatu perbuatan atau upaya untuk melindungi masyarakat dari perbuatan sewenang-wenang yang dilakukan penguasa, dan tidak sesuai dengan aturan hukum, untuk mewujudkan ketertiban dan ketentraman sehingga memungkinkan manusia untuk menikmati martabatnya sebagai manusia (Setiono, 2004).

c. Menurut Muchsin, perlindungan hukum merupakan kegiatan untuk melindungi individu dengan menyerasikan hubungan nilai atau kaidah yang dapat dilihat melalui sikap dan prilaku untuk menciptakan ketertiban dalam pergaulan hidup masyarakat (Muchsin, 2003).

Perlindungan hukum sangat erat kaitannya dengan kepastian hukum. Hukum merupakan sebuah sistem dibuat manusia untuk membatasi perilaku manusia agar tingkah laku manusia ini dapat terkontrol dalam kehidupan bermasyarakat. Hukum merupakan aspek paling penting dalam pelaksanaan sebuah rangkaian kekuasaan kelembagaan seperti kehidupan bernegara. Hukum secara tugas akan menjamin adanya kepastian peraturan dalam masyarakat. Maka dari itu, di setiap masyarakat akan memiliki hak mendapatkan pembelaan di mata hukum. Sehingga hukum dapat diartikan sebagai peraturan atau ketentuanketentuan tertulis dan tidak tertulis yang bertujuan untuk mengatur kehidupan masyarakat dan menyediakan sangsi bagi yang melakukan pelanggaran. Hal ini mungkin berbeda dengan hukum karma yang mungkin tidak memiliki efek secara langsung. Namun hukum buatan manusia tentu harus kita patuhi, jika tidak akan langsung berdampak pada sangsi. 


\section{Konsep Asuransi}

Asuransi atau dalam Bahasa Belanda diarikan sebagai verzekering, merupakan suatu pertanggungan yang terdiri dari 2 pihak, dimana salah satu pihak sanggup menanggung atau menjamin, dan pihak yang satu (Tertanggung) mendapat ganti rugi dari suatu kerugian, yang mungkin akan dideritanya sebagai akibat dari peristiwa yang belum tentu akan terjadi belum ditentukan akan terjadinya. Asuransi sebagai suatu perjanjian (timbal-balik) dengan mana seorang penanggung mengikatkan diri kepada seorang tertanggung dengan menerima suatu premi untuk memberikan penggantian kepadanya karena suatu kerugian, kerusakan, atau kehilangan keuntungan yang diharapkannya, yang mungkin akan dideritanya, karena suatu peristiwa tak tentu (onzeker voorval) (Prodjodikoro, 1996).

Pengertian asuransi sebenarnya juga sudah diatur secara limitatif dalam peraturan perundang-undangan. Dalam Kitab Undang-Undang Hukum Dagang disebutkan dalam Pasal 246 KUHD bahwa asuransi atau pertanggungan adalah perjanjian, dimana penanggung mengikat diri terhadap tertanggung dengan memperoleh premi, untuk memberikan kepadanya ganti rugi karena suatu kehilangan, kerusakan, atau tidak mendapat keuntungan yang diharapkan, yang mungkin akan diderita karena suatu peristiwa yang tidak pasti. Selain defenisi dari asuransi yang diberikan oleh KUHD, juga Undang - Undang No. 40 Tahun 2014 tentang Usaha Perasuransian juga memberikan defenisi dari asuransi. Dalam Ketentuan Pasal 1 angka (1) disebutkan bahwa Asuransi atau disebut juga dengan istilah pertanggungan merupakan perjanjian antara dua pihak yaitu dari perusahaan asuransi dan dari pemegang polis atau tertanggung asuransi, yang menjadi dasar bagi untuk menerima premi dari perusahaan asuransi sebagai imbalan untuk:

a. Memberikam penggantian kepada tertanggung atau pemegang polis karena kerugian, kerusakan, biaya yang timbul, kehilangan keuntungan, atau tanggung jawab hukum pada pihak ketiga yang akan dialami tertanggung, disebut juga pemegang polis karena terjadinya suatu peristiwa yang tidak pasti; atau

b. Memberikan pembayaran yang didasarkan pada meninggalnya tertanggung atau pembayaran yang didasarkan pada hidupnya tertanggung, adanya manfaat yang besarnya telah ditetapkan dan/atau didasarkan pada hasil pengelolaan dana.

Fungsi Asuransi: (a). Transfer Resiko: dengan membayar premi relatif kecil, seseorang atau perusahaan akan memindahkan ketidakpastian atas hidup dan harta bendanya (resiko) ke perusahaan asuransi. (b). Kumpulan Dana: Premi yang diterima kemudian dihimpun oleh perusahaan asuransi sebagai dana untuk membayar resiko yang terjadi.

Resiko yang dialihkan meliputi: kemungkinan kerugian material yang dapat dihitung dengan jumlah uang yang dirasakan tertanggung, sebagai akibat suatu peristiwa yang belum pasti terjadi (Uncertainty of Occurrence \& Uncertainty of Loss). Misalnya:

1. Resiko terbakarnya bangunan dan/atau Harta Benda di dalamnya sebagai akibat sambaran petir, kelalaian manusia, arus pendek.

2. Resiko kerusakan mobil karena kecelakaan lalu lintas, kehilangan karena pencurian.

3. Meninggal atau cedera akibat kecelakaan, sakit.

4. Banjir, Angin topan, badai, Gempa bumi, Tsunami.

Setiap asuransi pasti bermanfaat, yang secara umum manfaatnya adalah: (1). Memberikan jaminan adanya perlindungan terhadap berbagai risiko yang membawa kerugian yang diderita oleh satu pihak. (2). Meningkatkan efisiensi, oleh sebab tidak perlu secara special untuk membuat pengamanan dan juga adanya pengawasan guna memberikan perlindungan yang memakan banyak tenaga, waktu dan biaya. (3). Transfer Resiko, dengan membayar premi yang relatif kecil, seseorang atau 
perusahaan dapat memindahkan ketidakpastian atas hidup dan harta bendanya (resiko) ke perusahaan asuransi. (4). Pemerataan biaya, yaitu cukup hanya dengan mengeluarkan biaya yang jumlahnya tertentu dan tidak perlu mengganti/membayar sendiri kerugian yang timbul yang jumlahnya tidak tentu dan tidak pasti. (5). Sebagai acuan bagi pihak perbankan, agar dapat memberikan kredit karena bank memerlukan penjaminan perlindungan terhadap objek yang diagunkan, dan akan diserahkan oleh pihak peminjam uang. (6). Sebagai tabungan, karena jumlah yang dibayar kepada pihak asuransi akan memberikan kembali dengan jumlah yang lebih banyak. Hal ini berlaku pada asuransi jiwa. (7). Menutup adanya Loss of Earning Power kepadaseseorang atau badan usaha.

\section{Konsep Prinsip Good Corporate Governance (GCG)}

Terdapat 5 (lima) jenis prinsip GCG yang dapat dipakai sebagai dasar bagi para pelaku usaha, yaitu Transparency, Accountability, Responsibility, Indepandency dan Fairness yang biasanya disingkatkan dengan TARIF, yang mana diuraikan sebagai berikut:

1. Transparency (keterbukaan informasi); Secara umum dapat diartikan dengan istilah keterbukaan informasi. Dalam mewujudkan prinsip tersebut, pihak perusahaan wajib untuk menyediakan sarana informasi yang cukup memadai, akurat, tepat waktu kepada segenap stakeholders-nya.

2. Accountability (akuntabilitas); Yang dimaksud dengan akuntabilitas adalah kejelasan tugas dan fungsi, organisasi dalam struktur, sistem pertanggungjawaban daripada berbagai unsur dalam perusahaan. Jika prinsip ini dapat diterapkan secara baik dan efektif, maka terdapat kejelasan fungsinya, kejelasan akan hak, serta kejelasan dalam hal kewajiban serta wewenang atau tanggung jawab antara pemegang saham, dewan komisaris dan dewan direksi.
3. Responsibility (disebut dengan pertanggung jawaban); merupakan suatu jenis pertanggung jawaban dalam perusahaan, yang berkaitan dengan adanya kepatuhan pada perusahaan, terhadap berbagai peraturan yang berlaku, sebagai contoh yaitu masalah pajak, hubungan industrial, kesehatan dan keselamatan kerja, perlindungan lingkungan hidup, memelihara lingkungan bisnis yang kondusif bersama masyarakat dan sebagainya. Dengan menerapkan prinsip ini, diharapkan akan menyadarkan perusahaan bahwa dalam kegiatan operasionalnya, perusahaan juga mempunyai peran untuk bertanggung jawab kepada shareholder juga kepada stakeholders-lainnya.

4. Indepandency (kemandirian); Intinya, prinsip ini mensyaratkan agar perusahaan dikelola secara profesional tanpa ada benturan kepentingan dan tiada desakan berbentuk tekanan serta intervensi dari pihak manapun yang tidak sesuai dengan peraturan-peraturan yang berlaku.

5. Fairness (merupakan kesetaraan atau kewajaran), dimana pada prinsip ini mengingikan adanya pemberlakuan secara adil dalam memenuhi hak stakeholder sesuai dengan peraturan perundangan yang berlaku. Diharapkan fairness dapat menjadi salah satu pendorong yang akan memonitor serta adanya jaminan perlindungan yang adil di antara beragam kepentingan dalam perusahaan.

\section{Pengaturan Perlindungan Hukum Nasabah Asuransi}

Lembaga perusahaan perasuransian, hampir sama dengan lembaga perbankan, karena akan dipercaya apabila dapat memberikan jaminan kepercayaan kepada masyarakat. Perusahaan asuransi harus benar-benar dapat memberikan jaminan bahwa dana yang dikumpulkan akan dikembalikan di kemudian hari sesuai dengan hak nasabah. Masyarakat harus dapat diyakinkan bahwa perusahaan asuransi akan dapat memenuhi kewajibannya untuk membayar ganti rugi atas kerugian yang diderita oleh masyarakat 
tertanggung. Asuransi adalah perjanjian ganti rugi antara tertanggung dan penanggung yang aktanya disebut polis asuransi. Kontrak asuransi sangat spesifik karena hanya ditandatangani oleh penanggung (perusahaan asuransi), tetapi mengikat pihak tertanggung. Isi perjanjian umumnya disusun oleh perusahaan asuransi menjadi sesuatu yang baku atau standar. Isi kontrak asuransi di samping memuat bahasa-bahasa hukum, juga sangat teknis dan spesifik, di mana pada umumnya sangat sulit untuk memahami isi polis asuransi. Jangankan pihak tertanggung, banyak pelaku dalam perusahaan perasuransian juga kurang memahami isi kontrak.

Perlindungan hukum bagi nasabah asuransi dilihat dari 2 (dua) hal, yaitu:

Bentuk perlindungan yang diberikan kepada masyarakat oleh pemerintah melalui Otoritas Jasa Keuangan selanjutnya disingkat OJK yang telah diberikan hak untuk mengatur semua kegiatan perekonomian negara yang berhubungan dengan Perbankan dan Lembaga Keuangan Bukan Bank, dengan dibentuknya UndangUndang No. 21 Tahun 2001 tentang Otoritas Jasa Keuangan, harus mengatur permodalan pada perusahaan asuransi sehingga diharapkan perkembangan sektor ekonomi ini akan menguntungkan negara secara lebih besar. Selanjutnya dengan pembentukan Otoritas Jasa Keuangan (OJK) di Indonesia secara jelas telah disebutkan dalam Undang-Undang Bank Indonesia yang merupakan Undang-undang organik sebagai pelaksanaan dari Pasal 23D UUD 1945 , sehingga nampak terdapat materi sisipan untuk pembentukan Lembaga Pengawas Jasa Keuangan (sekarang disebut dengan Otoritas Jasa Keuangan). OJK memiliki kewenangan terhadap beberapa sektor penting penunjang perekonomian Indonesia antara lain: Lembaga perbankan; Pasar Modal; Perasuransian; dana pensiun dan lembaga pembiayaan.

Otoritas Jasa Keuangan (OJK) dibentuk dengan tujuan agar keseluruhan kegiatan di dalam sektor jasa keuangan: a. Terselenggara secara teratur, adil, transparan dan akuntabel;

b. Mampu mewujudkan sistem keuangan yang tumbuh secara berkelanjutan dan stabil;

c. Mampu melindungi kepentingan konsumen dan masyarakat.

\section{Perlindungan Hukum menurut Undang- undang No 40 Tahun 2014}

Pada Pasal 53 ayat (1) Undangundang No 40 Tahun 2014 berbunyi "Perusahaan Asuransi dan perusahaan asuransi Syariah wajib menjadi peserta program penjaminan polis". Kata "Program" dalam Pasal 53 dalam penjelasan undang-undang ini apa saja program yang dimaksudkan agar tidak terjadi multitafsir dalam Pasal ini. Apabila program yang dimaksudkan nantinya berhubungan dengan adanya pembentukan suatu Lembaga penjamin polis maka akan lebih memberikan kepastian hukum bagi pemegang polis dibandingkan hanya dengan Program penjaminan polis. Pembentukan sebuah lembaga penjamin polis merupakan kumpulan perusahaan asuransi yang para pemegang sahamnya adalah perusahaan-perusahaan asuransi yang ada.

\section{Penerapan Prinsip Good Corporate Governance Pada Perusahaan Asuransi}

Tata Kelola Perusahaan yang baik merupakan suatu rangkaian mekanisme atau sistem yang mengarahkan dan mengendalikan perusahaan agar sesuai dengan harapan para pemangku kepentingan (stakeholders) dengan mendasarkan pada prinsip-prinsip Good Corporate Governance (GCG) sebagai dasar peningkatan kinerja perusahaan, dengan dilakukannya pemutakhiran seluruh perangkat GCG secara terus menerus.

Penerapan prinsip-prinsip GCG bagi perusahaan asuransi saat ini memasuki era baru dengan diperkenalkannya GCG Sektor Perasuransian menjadikan perusahaan asuransi perlu memastikan bahwa proses bisnis yang dilakukan telah berdasarkan 
pada ketentuan ini. Pedoman GCG perasuransian yang telah diterbitkan merupakan langkah awal yang patut dihargai dan memerlukan penjabaran dalam penerapnnya. Demikian pula suatu saat nanti penerapan GCG bisa dijadikan salah satu faktor dalam menilai peringkat (rating) perusahaan asuransi serta menjadi bahan pertimbangan bagi calon pemegang polis dalam memilih suatu perusahaan asuransi.

Mekanisme atau sistem ini mempengaruhi penetapan dan pencapaian tujuan perusahaan, pemantauan dan penilaian risiko usaha, memaksimalkan upaya peningkatan kinerja dan pembentukan serta pengembangan budaya kerja di lingkungan perusahaan. Bagi suatu Perusahaan Asuransi, penerapan tata kelola perusahaan yang baik bukan hanya sekadar kewajiban, namun sudah merupakan suatu keniscayaan untuk menjaga transparansi dan akuntabilitas pengelolaan perusahaan kepada publik. Pengembangan GCG selaras dengan best practices yang dilakukan secara berkelanjutan

\section{Simpulan}

1. Perlindungan hukum bagi nasabah asuransi, dapat dikaji melalui:

a. Peranan Otoritas Jasa Keuangan (OJK), yang telah diberikan hak untuk mengatur semua kegiatan perekonomian negara yang berhubungan dengan Perbankan dan Lembaga Keuangan Bukan Bank, dengan dibentuknya Undang-Undang No. 21 Tahun 2001 tentang Otoritas Jasa Keuangan, harus mengatur permodalan pada perusahaan asuransi sehingga diharapkan perkembangan sektor ekonomi ini akan menguntungkan negara secara lebih besar. b. Perlindungan Hukum menurut Undangundang No 40 Tahun 2014, Pada Pasal 53 ayat (1) Undang-undang No 40 Tahun 2014 berbunyi "Perusahaan Asuransi dan perusahaan asuransi Syariah wajib menjadi peserta program penjaminan polis", program yang dimaksudkan nantinya berhubungan dengan adanya pembentukan suatu Lembaga penjamin polis maka akan lebih memberikan kepastian hukum bagi pemegang polis

2. Wujud implementasi atau pelaksanaan Good Corporate Governance (GCG) yang telah dilakukan perusahaan asuransi antara lain: Memiliki Perangkat Pedoman Penerapan GCG dan Assessment terhadap Penerapan GCG.

\section{Referensi}

Abbas, A Salim. Dasar-Dasar Asuransi. PT Raja Grafindo, Jakarta, 1993

Azhary, Negara Hukum Indonesia, Analisis Yuridis Normatif tentang Unsurunsurnya, Jakarta Press, 1995.

Hadjon Philipus M, Perlindungan Hukum Bagi Rakyat Indonesia, Sebuah Studi tentang Prinsip-prinsipnya, Penanganan Oleh pengadilan dalam Lingkungan Peradilan umum dan Pembentukan Peradilan administrasi, Surabaya, Peradaban, 2007.

Ibrahim Jhonny, Teori dan Metodologi Penelitian hukum Normatif, 2008.

Muchsin, "Perlindungan dan Kepastian Hukum bagi Investor di Indonesia," (Surakarta: Magister Ilmu Hukum Program Pascasarjana Universitas Sebelas Maret, 2003).

Setiono, "Rule of Law (Supremasi Hukum)," (Surakarta : Magister Ilmu Hukum Program Pascasarjana Universitas Sebelas Maret, 2004).

UUD NRI 1945

Republik Indonesia, Undang-undang Nomor 2 Tahun 1992 tentang Usaha Perasuransian.

40 Tahun 2014 tentang Perasuransian. , Undang-Undang No.

21 Tahun 2011 tentang Otoritas Jasa Keuangan. 